\title{
Surveillance of Chagas disease vectors in Ceará State, Northeastern Brazil
}

\section{Vigilância dos vetores da Doença de Chagas no Estado do Ceará, Nordeste do Brasil}

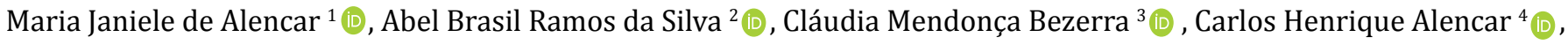 \\ Victor Emanuel Pessoa Martins ${ }^{5}$ (i)
}

1. Discente do Curso de Ciências Biológicas, Universidade da Integração Internacional da Lusofonia Afro-Brasileira (UNILAB), Redenção, CE, Brasil. 2. Empresa Brasileira de Serviços Hospitalares (EBSERH), Fortaleza, CE, Brasil. 3. Célula de Vigilância Epidemiológica, Secretaria de Saúde do Estado do Ceará (SESA-CE), Fortaleza, CE, Brasil. 4. Departamento de Saúde Comunitária, Faculdade Medicina, Universidade Federal do Ceará (UFC), Fortaleza, CE, Brasil. 5. Instituto de Ciências Exatas e da Natureza, Universidade da Integração Internacional da Lusofonia Afro-Brasileira (UNILAB), Redenção, CE, Brasil.

\begin{abstract}
Objective: Describe the spatial distribution, temporal trend and the natural infection rates by Trypanosoma cruzi in triatomines captured in Ceará State, between 2003 and 2014. Methods: Chagas Disease Control Program data were used to describe triatomine species circulating, their distribution in the state, the capture places (intradomicile and peridomicile), and the rates of natural infection by T. cruzi, between 2003 and 2014 . Results: During this period, 401,721 triatomines were captured in $89.1 \%$ of the municipalities of the State, belonging to the species Triatoma pseudomaculata (53.9\%), Triatoma brasiliensis (40.5\%), Rhodnius nasutus (1.9\%), Panstrongylus megistus (1.5\%), Panstrogylus lutzi (1.3\%), Triatoma rubrofasciata (0.8\%), Panstrongylus geniculatus $(<0.1 \%)$, and Triatoma petrochiae $(<0.1 \%)$. Most of the specimens were caught in peridomicile areas $(83.0 \%)$, with emphasis on T. pseudomaculata and T. brasiliensis, while P. lutzi was predominant in the intradomicile. P. lutzi had the highest infection rate by T. cruzi (7.8\%), while T. pseudomaculata $(0.9 \%)$, T. brasiliensis (1.0\%), and P. megistus $(1.3 \%)$ had the lowest rates. Conclusions: The occurrence of an enzootic cycle of T. cruzi and the presence of synanthropic animals that provide a source of blood meals to triatomines increases the risk of its transmission to humans, requiring constant vigilance by the sanitary authorities.
\end{abstract}

Keywords: Triatominae; Surveillance; Chagas's Disease.

\section{Resumo}

Objetivo: Descrever a distribuição especial, tendência temporal e a as taxas de infecção natural por T. cruzi em triatomíneos capturados no Estado do Ceará, entre 2003 e 2014. Métodos: Dados do Programa de Controle da Doença de Chagas foram utilizados para descrever as espécies de triatomíneos circulantes, sua distribuição no Estado, os locais de captura (intradomicílio e peridomicílio) e as taxas de infecção natural por T. cruzi entre os anos de 2003 e 2014. Resultados: Durante este período, 401.721 triatomíneos foram capturados em 89,1\% dos municípios do Estado, pertencendo às espécies Triatoma pseudomaculata (53,9\%), T. brasiliensis (40,5\%), Rhodnius nasutus $(1,9 \%)$, Panstrongylus megistus $(1,5 \%)$, P. lutzi $(1,3 \%)$, T. rubrofasciata (0,8\%), P. geniculatus $(<0,1 \%)$ e T. petrochiae $(<0,1 \%)$. A maioria dos espécimes foi capturada no peridomicílio $(83,0 \%)$, com destaque para T. pseudomaculata e T. brasiliensis, enquanto P. lutzi foi predominante no intradomicílio. P. lutzi teve a maior taxa de infecção por T. cruzi (7,8\%), enquanto T. pseudomaculata $(0,9 \%)$, T. brasiliensis $(1,0 \%)$ e P. megistus $(1,3 \%)$ tiveram as menores taxas. Conclusões: A ocorrência de um ciclo enzoótico de T. cruzi e a presença de animais sinantrópicos que proporcionam uma fonte de alimentação sanguínea aos triatomíneos aumentam o risco de sua transmissão aos humanos, exigindo das autoridades sanitárias uma vigilância constante desses vetores.

Palavras-chave: Triatomíneos; Vigilância; Doença de Chagas.

\section{INTRODUCTION}

Chagas disease (American trypanosomiasis) is a chronic parasitic infection, where it is currently estimated that 6-7 million people carry the disease, and 50-60 million people are at risk of acquiring the infection ${ }^{1}$. In Brazil, it is considered an important public health problem due to its high prevalence, extensive geographical distribution, and high lethality of clinical forms ${ }^{2}$. It is caused by the flagellate protozoan Trypanosoma cruzi (Kinetoplastida, Trypanosomatidae), which is transmitted primarily by blood-sucking insects belonging to the subfamily Triatominae (Hemiptera, Reduviidae), and can infect a wide range of mammals. Although triatomines can feed on other vertebrates, such as birds and reptiles, these animals are refractory to infection ${ }^{3}$.

Several triatomine species are of great epidemiological importance due to their high susceptibility to $T$. cruzi infection as well as their ability to invade and colonize artificial ecotopes in dwellings ${ }^{4}$. The incidence and prevalence rates of Chagas disease associated with vector transmission have been decreasing in Brazil, thus the oral infection currently represents the main form of transmission of $T$. cruzi to humans and domestic animals. Once infected, triatomines can contaminate food and other household items with their urine and feces ${ }^{5}$. 
Chemical control of triatomine populations through spraying of insecticides in dwellings has contributed to reducing the vector transmission of Chagas disease ${ }^{6}$. However, in regions where wild species of triatomines are abundant, the weak residual effect of insecticides associated with environmental degradation in areas surrounding cities facilitates the invasion and colonization of dwellings by wild triatomines ${ }^{7}$.

The Brazilian Northeast region plays an important role in the national epidemiology of Chagas disease. In this region, the state of Ceará is an endemic area of Chagas disease, predominantly in the Caatinga biome. The occurrence of precarious human dwellings in the state's rural areas facilitates the presence of Triatoma brasiliensis, Triatoma pseudomaculata, Panstrongylus megistus, Panstrongylus lutzi, and Rhodnius nasutus, important vectors of $T$. cruzi ${ }^{8}$. In this scenario, peridomestic environments, including corrals, pigpens, and chicken coops, can form a link between the sylvatic and the domestic cycle of Chagas disease transmission, since native triatomines can establish large peridomestic colonies ${ }^{9}$.

The objective of this study was to describe the epidemiological importance of triatomines in maintaining the circulation of T. cruzi in Ceará, between 2003 and 2014, by identifying the species that are circulating, their distribution in the state, the capture places (intradomicile and peridomicile) and the rates of natural infection by $T$. cruzi.

\section{METHODS}

The state of Ceará is composed of 184 municipalities and covers an area of $148,825.60 \mathrm{~km} 2$, making it the fourth-largest state by area in the Northeast region of Brazil. Most of its territory has a semiarid climate, with a diverse range of landscapes and vegetation patterns, the standout being the Caatinga (shrubland) biome ${ }^{10}$ (Figure 1).

This is a descriptive ecological study based on secondary data obtained from the Nucleus for Control of Vectors of the Ceará State Health Secretariat. The data refer to the vectorial control activities performed by municipalities to capture triatomines in the state between 2003 and 2014. The data identified the capture place (intradomicile or peridomicile) of triatomine adults and nymphs and the rate of natural infection by $T$. cruzi (number of triatomines infected by $T$. cruzi / number of triatomines examined $x$ 100). The insects were identified according to a specific classification key11, while the presence of T. cruzi in the insects examined was detected by the abdominal compression method. In this case, the abdominal content of each triatomine was placed on a slide, mixed with a $0.9 \%$ saline solution and covered with a coverslip for analysis with an optical microscope.

The geographic database was formed by data on the number of captured, examined, and positive triatomines from 2003 to 2014 in Ceará, subdivided by municipalities. This database was indexed by the municipality and saved in the dBase format.
Figure 1. Map of South America, with Brazil, its Northeast region and the state of Ceará in highlight

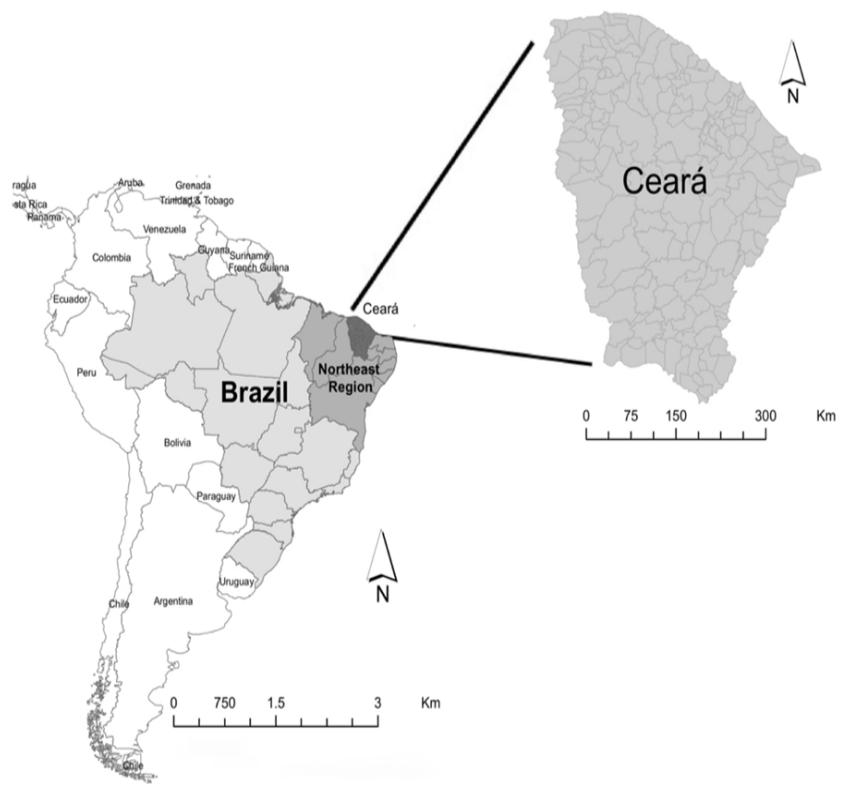

From this database, two indicators were used: the number of captured triatomines and the proportion of positive triatomines among those examined. These two indicators were used to make descriptive thematic maps to identify spatial patterns of triatomine distribution in Ceará. The ArcGis 9.2 software was used to create the maps (ESRI - Environmental Systems Research Institute, Redlands, CA, USA, 2010).

\section{RESULTS}

During the period studied, the control and surveillance activities for Chagas disease were carried out in 164 (89.1\%) municipalities in Ceará. In these municipalities, 401,721 triatomines were captured (adults and nymphs) in intradomicile and peridomicile areas of the dwelling units (DUs) investigated, with emphasis on T. pseudomaculata $(216,425-53.9 \%)$ and $T$. brasiliensis (162,594 - 40.5\%) (Table 1$)$.

In general, there was observed a decrease in the number of insects captured along the period of the study, with a significant reduction from 46,852 in 2003 to 18,242 in 2014. The highest number of captured insects was observed in 2006, while 2011 was the year with the lowest record of catches. The most intense reduction was for the species $T$. pseudomaculata and $T$. brasiliensis. $P$. megistus, $P$. lutzi and $R$. nasutus also showed a reduction in the period, showing fluctuations from the year 2010. The other species showed few catches over time.

Regarding the distribution of species, T. brasiliensis was found in 157 (95.7\%) municipalities, followed by T. pseudomaculata (155 - 94.5\%), P. lutzi (153 - 93.3\%), R. nasutus (138-84.1\%), and $P$. megistus (97 - 59.1\%), these being the species with the greatest distribution in the State. P. geniculatus was found in 17 (10.4\%) municipalities, Triatoma petrchiae had its occurrence restricted to $2(1.2 \%)$ municipalities, and T. rubrofasciata was found only in $1(0.6 \%)$ municipality, the capital Fortaleza (Figure 2$)$. 
Table 1. Triatomines (adults and nymphs) captured in the state of Ceará, 2003 to 2014.

\begin{tabular}{|c|c|c|c|c|c|c|c|c|c|c|c|c|c|}
\hline \multirow[t]{2}{*}{ Species } & \multicolumn{12}{|c|}{ Years of Capture } & \multirow[t]{2}{*}{ Total } \\
\hline & 2003 & 2004 & 2005 & 2006 & 2007 & 2008 & 2009 & 2010 & 2011 & 2012 & 2013 & 2014 & \\
\hline T. brasiliensis & 18,071 & 17,001 & 19,142 & 21,417 & 19,378 & 14,021 & 8,213 & 10,474 & 8,270 & 10,887 & 6,301 & 9,419 & 162,594 \\
\hline T. pseudomaculata & 26,833 & 24,279 & 32,886 & 29,225 & 26,369 & 17,196 & 12,918 & 14,661 & 8,391 & 11,075 & 5,165 & 7,427 & 216,425 \\
\hline T. rubrofasciata & 0 & 203 & 162 & 354 & 608 & 661 & 147 & 62 & 608 & 21 & 144 & 240 & 3,210 \\
\hline T. petrochiae & 0 & 0 & 0 & 0 & 0 & 0 & 0 & 2 & 0 & 0 & 0 & 0 & 2 \\
\hline P. megistus & 563 & 374 & 597 & 851 & 1,106 & 855 & 492 & 259 & 255 & 351 & 173 & 253 & 6,129 \\
\hline P. lutzi & 485 & 401 & 632 & 660 & 656 & 498 & 271 & 232 & 372 & 359 & 323 & 467 & 5,356 \\
\hline P. geniculatus & 0 & 0 & 36 & 15 & 28 & 18 & 12 & 6 & 8 & 27 & 68 & 7 & 225 \\
\hline R. nasutus & 900 & 817 & 1,046 & 952 & 1,086 & 651 & 362 & 319 & 277 & 555 & 386 & 429 & 7,780 \\
\hline
\end{tabular}

Figure 2. Distribution of the species of triatomines captured in the state of Ceará, 2003 to 2014.
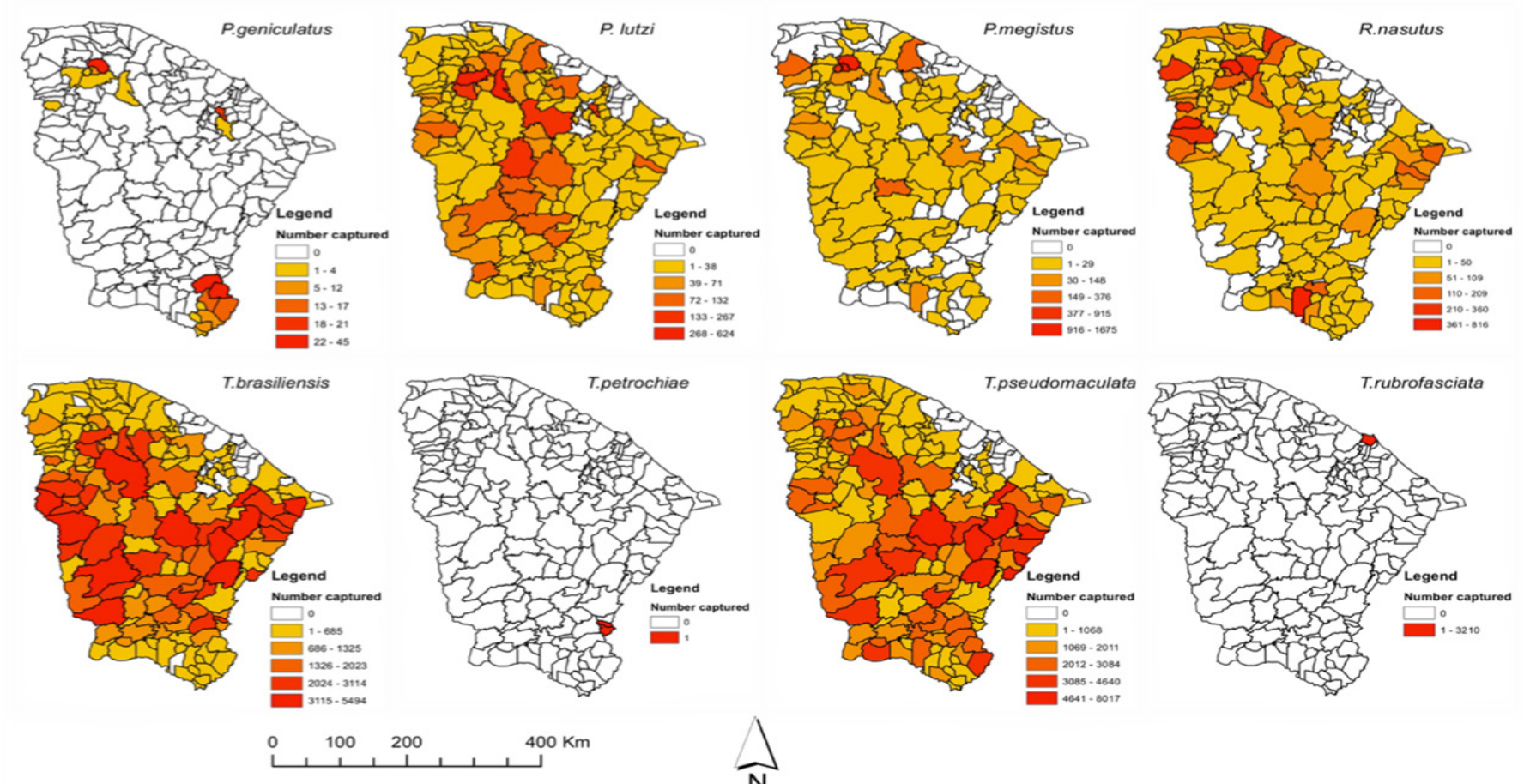

$\triangle$ 


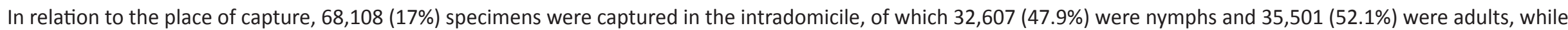
$333,613(83 \%)$ specimens were captured in the peridomicile, with 211,674 (63.4\%) nymphs and 121,939 (36.6\%) adults (Table 2 ).

Table 2. Frequency of triatomine nymphs and adults captured in intradomicile and peridomicile areas in the state of Ceará, 2003 to 2014.

\begin{tabular}{|c|c|c|c|c|c|c|c|c|c|c|c|}
\hline \multirow[t]{3}{*}{ Species } & \multicolumn{5}{|c|}{ Intradomicile } & \multicolumn{5}{|c|}{ Peridomicile } & \multirow[t]{3}{*}{ p-valor } \\
\hline & \multirow{2}{*}{$\begin{array}{ll}\text { Nymph } \\
\mathrm{N}\end{array}$} & \multicolumn{3}{|c|}{ Adult } & \multirow[t]{2}{*}{ Total } & \multirow{2}{*}{$\begin{array}{r}\text { Nymph } \\
\mathrm{n}\end{array}$} & \multicolumn{3}{|c|}{ Adult } & \multirow[t]{2}{*}{ Total } & \\
\hline & & $\%$ & $\mathrm{n}$ & $\%$ & & & $\%$ & $\mathrm{~N}$ & $\%$ & & \\
\hline T. brasiliensis & 25,019 & 52.2 & 22,928 & 47.8 & 47,947 & 73,292 & 63.9 & 41,355 & 36.1 & 114,647 & $<0.001$ \\
\hline T.pseudomaculata & 6,243 & 49.3 & 6,427 & 50.7 & 12,670 & 130,974 & 64.3 & 72,781 & 35.7 & 203,755 & $<0.001$ \\
\hline T. rubrofasciata & 554 & 47.2 & 620 & 52.8 & 1,174 & 1,288 & 63.3 & 748 & 36.7 & 2,036 & $<0.001$ \\
\hline T. petrochiae & 0 & 0.0 & 2 & 100 & 2 & 0 & 0.0 & 0 & 0.0 & 0 & - \\
\hline P. megistus & 436 & 37.7 & 719 & 62.3 & 1,155 & 2,645 & 53.2 & 2,329 & 46.8 & 4,974 & $<0.001$ \\
\hline P. lutzi & 129 & 3.1 & 3,994 & 96.9 & 4,123 & 348 & 28.2 & 885 & 71.8 & 1,233 & $<0.001$ \\
\hline P. geniculatus & 12 & 10.7 & 100 & 89.3 & 112 & 56 & 49.6 & 57 & 50.4 & 113 & $<0.001$ \\
\hline R. nasutus & 214 & 23.1 & 711 & 76.9 & 925 & 3,071 & 44.8 & 3,784 & 55.2 & 6,855 & $<0.001$ \\
\hline Total & 32,607 & & 35,501 & & 68,108 & 211,674 & & 121,939 & & 333,613 & \\
\hline
\end{tabular}

p-value $<0.001$ represents results with high significance.

Regarding the natural infection by T. cruzi, 350,990 (87.4\%) triatomines were examined (Table 3). T. brasiliensis, T. pseudomaculata, P. megistus, P. lutzi, P. geniculatus, and R. nasutus exhibited different infection rates, varying according to the municipalities of their occurrence, while no specimen of T. rubrofasciata and T. petrochiae was found infected with $T$. cruzi (Figure 3). Among the species captured, P. lutzi presented proportionally the highest infection rate for T. cruzi (7.8\%), while T. pseudomaculata, T. brasiliensis, and P. megistus showed the lowest infection rates $(0.9 \%, 1 \%$, and $1.3 \%$, respectively) (Table 3$)$.

Table 3. Triatomines examined and infected by T. cruzi and infection rate in Ceará State, 2003 to 2014.

\begin{tabular}{lrrr}
\hline Species & Examined & Infected by T. cruzi & Infection rate \\
\hline T. brasiliensis & 141.729 & 1.354 & $1 \%$ \\
T. pseudomaculata & 191.835 & 1.775 & $0,9 \%$ \\
T. rubrofasciata & 2.774 & 0 & 0 \\
T. petrochiae & 2 & 0 & 0 \\
P. megistus & 5.356 & 69 & $1,3 \%$ \\
P. lutzi & 3.906 & 304 & $7,8 \%$ \\
P. geniculatus & 229 & 9 & $3,9 \%$ \\
R. nasutus & 5.159 & 127 & $2,5 \%$ \\
\hline
\end{tabular}


The use of smartphones in ophthalmology: technological development and application

\section{DISCUSSION}

Brazil's Northeast region has an important epidemiological role involving Chagas disease due to the presence of a large number of substandard dwellings that triatomines can invade and colonize, the existence of a diverse triatomine fauna, and the dispersion of T. brasiliensis and T. pseudomaculata, species that are hard to control ${ }^{12}$.

The first reports of the presence of triatomines in Ceará date to the 1920s, when physician Gavião Gonzaga recorded the presence of $P$. megistus and Rhodnius prolixus in dwellings ${ }^{19}$. Since then, several entomological investigations have been conducted, most of them associated with the Program to Control Chagas Disease between 1975 and 2002. These campaigns recorded a diverse triatomine fauna, represented principally by T. brasiliensis (58.3\%), T. pseudomaculata (37.8\%), R. nasutus (2.3\%), P. megistus (1.9\%), and P. lutzi (0.5\%)13. In our study, however, besides the occurrence of $T$. rubrofasciata, T. petrochiae, and $P$. geniculatus, T. pseudomaculata had greater prevalence than $T$. brasiliensis, as also observed by other researchers ${ }^{14}$.

T. brasiliensis and T. pseudomaculata have become particularly important since they have been found widely infesting human dwellings in Northeast Brazil15. Both are found naturally infected by $T$. cruzi ${ }^{24}$, but with a significantly low natural infection rate, as observed in this study. Although low, the infection rates of $T$. brasiliensis by $T$. cruzi tend to be greater than observed in the case of $T$. pseudomaculata, which can be related to the great diversity of food resources and to the greater ability of T. brasiliensis to ingest blood in relation to T. pseudomaculata, making this one less able to transmit $T$. cruzi ${ }^{16}$.

In general, we observed that both species occurred with greater frequency in peridomicile areas, as also reported by other researches ${ }^{26}$. Nevertheless, when analyzing the development stage of the insects and place of capture, we observed that adult forms predominated inside dwellings, while nymphs were more abundant in peridomicile areas. Genetically distinct populations of $T$. brasiliensis were identified living in wild, domestic, and peridomestic habitats, suggesting that the peridomestic environment acts as a bridge between the wild and domestic ecotopes ${ }^{17}$. The ecological eclecticism of $T$. brasiliensis and T. pseudomaculata of inhabiting a wide variety of domestic, peridomestic, and wild ecotopes appears to be the main obstacle to the effective control of their populations by intradomicile spraying of insecticides because after the residual effects of these chemicals fades, the dwellings are recolonized by insects from peridomestic and/or wild habitats ${ }^{18}$.

R. nasutus is considered the third most important triatomine species found in Brazil's semiarid Northeast region. Its widespread distribution in Ceará, combined with its significant natural infection rate by $T$. cruzi and high peridomicile presence19 were also observed in this study. This species is predominantly wild, usually associated with palm trees, but it has been frequently found colonizing artificial peridomicile and intradomicile ecotopes. The proximity between palm trees and dwellings and the use of palm trunks for roof structures are important factors for the infestation of dwellings by $R$. nasutus, which makes it a potential link in the domestic chain of T. cruzi transmission ${ }^{20}$.

P. geniculatus is an important wild vector that is sporadically found inside residences and is usually found to have a high natural infection rate by $T$. cruzi ${ }^{21}$. It had the second-highest infection rate by $T$. cruzi in this study, with the predominance of nymphs in peridomicile areas, while adults were more abundant inside dwellings, corroborating the domiciliation trend of this species ${ }^{22}$, which can contribute to the domiciliary transmission of Chagas disease.

With occurrence restricted to the Caatinga biome of Northeast Brazil, where it inhabits domestic and peridomestic environments, $P$. lutzi is considered to be an important species for maintenance of the enzootic cycles $T$. cruzi, since it feeds on the blood of a large variety of animal species ${ }^{23}$. The occurrence of nymphs and adults in intradomicile and peridomicile areas observed in this study warrants attention regarding the high risk of the establishment of colonies inside dwellings ${ }^{24}$. Furthermore, the high infection rate by $T$. cruzi observed in this study $(7.8 \%)$ indicates a high risk of domiciliary transmission of Chagas disease by this species.

Widely distributed throughout Brazil, P. megistus is highly eclectic regarding ecotopes inhabited. It is mainly found inside dwellings in the Northeast and Southeast regions, while in the South it is mainly considered a wild species ${ }^{43}$. More than $80 \%$ of the specimens of $P$. megistus captured in this study inhabited peridomicile areas, with the colonization of these habitats (presence of a large number of nymphs) being strongly influenced by the presence of domesticated birds, especially chickens, which are an important food source for triatomines ${ }^{25}$. Although they are refractory to infection by $T$. cruzi, the birds present a strong link between the wild and domiciliary environments, exposing people to the risk of infection by the parasite.

In semiarid areas of northeastern Brazil, members of the Triatoma brasiliensis complex, which is comprised of six species (T. bahiensis, T. juazerensis, T. lenti, T. melanica, T. petrocchiae, and $T$. sherlocki) and two subspecies (Triatoma brasiliensis brasiliensis and Triatoma brasilieneis macromelasoma), are the main Chagas disease vectors, except for T. petrocchiae, which seems to be entirely wild, without epidemiological significance ${ }^{26}$. T. petrochiae was not found infected by $T$. cruzi in Ceará during the period of this study. Its occurrence (only 2 specimens) was reported in 2010 inside dwellings in 2 municipalities in the southern region of the state, near the borders to the east with the states of Rio Grande do Norte and Paraíba, where T. petrochiae was recently found in cohabitation 
with $T$. brasiliensis in rocky outcrops ${ }^{27}$.

T. rubrofasciata is a tropicopolitan species totally domiciliated with urban characteristics, closely related to socioeconomic factors of many cities, especially areas near the coast. Although it has been found naturally infected by $T$. cruzi ${ }^{28}$, it is normally found to be infected by Trypanosoma conorrhini, which is not pathogenic to humans ${ }^{29}$. T. rubrofasciata, which does not have epidemiological importance for Chagas disease among the domiciliated triatomine species, was only found in the municipality of Fortaleza, without infection by T. cruzi.

The constant presence of synanthropic animals in the home environment has been shown to be an important risk factor for the transmission of $T$. cruzi to humans in Northeastern Brazil, not only through the vector route, but, mainly, via the oral route since the increasing domiciliation of triatomines infected with $T$. cruzi favors the contamination of food used by a man with the feces of these insects. In this sense, it is important to highlight the need to reinforce care with the hygiene of food before consumption, especially those consumed in natura, in addition to the systematization of vector control actions by health authorities.

This study had limitations related to secondary data are taken from the Nucleus for Control of Vectors of the Ceará State Health Secretariat, such as some fields being inadequately filled in, as well as missing or incomplete information. However, this did not compromise the information, given the large volume of notifications.

\section{ACKNOWLEDGEMENTS:}

We thank the Nucleus for Control of Vectors of the Ceará State Health Secretariat for a partnership project by allowing access to the database obtained from the field actions of the Chagas Disease Control Program in the State of Ceará.

\section{REFERENCES}

1. Chagas disease in Latin America: an epidemiological update based on 2010 estimates. Wkly Epidemiol Rec. 2015 Feb; 90(6): 33-44.

2. Schmunis GA. Tripanosomíase americana: Seu impacto nas Américas e perspectivas de controle. In: Dias JCP, Coura JR, organizadores. Clínica e Terapêutica da Doença de Chagas. Rio de Janeiro: Editora Fiocruz; 1997. p. 1123.

3. Galvão C, Justi SA. An overview on the ecology of Triatominae (Hemiptera: Reduviidae). Acta Trop. 2015 Nov; 151: 116-125. doi:10.106/ jactatropica.2015.06.006.

4. Parente CC, Bezerra FSM, Parente PI, Dias-Neto RV, Xavier SCC, Ramos AN, et al. Community-Based Entomological Surveillance Reveals Urban Foci of Chagas Disease Vectors in Sobral, State of Ceará, Northeastern Brazil. PLoS One. 2017 Jan; 12(1): e0170278. doi:10.1371/ journal.pone.0170278.

5. Dias JCP, Neto VA, Luna EJA. Mecanismos alternativos de transmissão do Trypanosoma cruzi no Brasil e sugestões para sua prevenção. Rev Soc Bras Med Trop. 2011 Maio-Jun; 44(3): 375-9. doi:10.1590/S0037-86822011005000032.

6. Guhl F. Chagas disease in Andean countries. Mem Inst Oswaldo Cruz. 2007 Out; 201(Suppl): 29-38. doi:10.1590/S0074-02762007005000099.

7. Coutinho CFS, Souza-Santos R, Teixeira NFD, Georg I, Gomes TF, Boia $\mathrm{MN}$, et al. An entomological investigation of Chagas disease in the state of Ceará, Northeast Region of Brazil. Cad Saude Publica. 2014; 30(4): 785-93. doi:10.1590/0102-311X00176512.

8. Gurgel-Gonçalves R, Galvão C, Costa J, Peterson A. Geographic distribution of Chagas disease vectors in Brazil based on ecological niche modeling. J Trop Med. 2012; 2012: 1-15. doi:10.1155/2012/705326.

9. Sarquis O, Sposina R, Oliveira TG, MacCord JR, Cabello PH, Borges-Pereira J, et al. Aspects of peridomiciliary ecotopes in rural areas of Northeastern Brazil associated to triatomine (Hemiptera, Reduviidae) infestation, vectors of Chagas disease. Mem Inst Oswaldo Cruz. 2006 Mar; 101(2): 143-7. doi:10.1590/S007402762006000200005

10. Instituto de Planejamento do Ceará. Atlas do Ceará. Fortaleza: Governo do Estado do Ceará; 1997. 65p.

11. Lent $H$, Wygodzinsky P. Revision of the Triatominae (Hemiptera, Reduviidae) and their significance as vectors of Chagas' disease. Bull Am Mus Nat Hist. 1979; 163: $123-520$
12. Dias JCP, Machado EMM, Fernandes AL, Vinhaes MC. Esboço geral e perspectivas da doença de Chagas no Nordeste do Brasil. Cad Saude Publica. 2000; 16( Suppl 2):13-34. doi:10.1590/\$0102-311X2000000800003.

13. Silva ADG, Pontes RJS, Alencar CHM, Ramos Júnior NA, Lima JWO. Avaliação do Programa de Controle da Doença de Chagas no Estado do Ceará: período de gestão federal, 1975 a 2002. Cad Saude Colet. 2009 Abr; 16(4): 873-892. doi: https://doi.org/10.1590/S0102-311X2009000400022.

14. Fidalgo ASOBV, Costa AC, Silva JD Filho, Cândido DS, Freitas EC, Pereira LS, et al. Insect vectors of Chagas disease (Trypanosoma cruzi) in Northeastern Brazil. Rev Soc Bras Med Trop. 2018 Mar-Apr; 51(2): 174-182. doi:10.1590/0037-86820408-2017.

15. Costa J, Almeida CE, Dotson EM, Lins A, Vinhaes MC, Silveira AC, et al. The epidemiologic importance of Triatoma brasiliensis as a Chagas disease vector in Brazil: a revision of domiciliary captures during 1993-1999. Mem Inst Oswaldo Cruz. 2003; 98(4): 443-449. doi:10.1590/S0074-02762003000400002.

16. Soares RPP, Evangelista LG, Laranja LS, Diotaiuti L. Population dynamics and feeding behavior of Triatoma brasiliensis and Triatoma pseudomaculata, main vectors of Chagas Disease in Northeastern Brazil. Mem Inst Oswaldo Cruz. 2000 Mar-Apr; 95(2): 151-5. doi:10.1590/S0074-02762000000200003.

17. Borges EC, Dujardin JP, Schofield CJ, Romanha AJ, Diotaiuti L. Dynamic between sylvatic, peridomestic and domestic populations of Triatoma brasiliensis (Hemiptera: Reduviidae) in Ceará State, Northeastern Brazil. Acta Trop. 2005; 93(1): 119-126. doi:10.1016/j.actatropica.2004.10.002.

18. Oliveira Lima JW, Faria Filho OF, Vieira JBF, Gadelha FV, Oliveira AM Filho. Alterações do peridomicílio e suas implicações para o controle do Triatoma brasiliensis. Cad Saude Publica. 2000; 16(Supl. II): 75-8. doi:10.1590/S0102$311 \times 2000000800008$

19. Lima MM, Sarquis O, Oliveira TG, Gomes TF, Coutinho C, Daflon-Teixeira NF, et al. Investigation of Chagas Disease in four periurban areas in northeastern Brazil: epidemiologic survey in man, vectors, non-human hosts and reservoirs. Trans $R$ Soc Trop Med Hyg. 2012 Mar; 106(3): 143-9. doi:10.1016/j.trstmh.2011.10.013.

20. Dias FBS, De Paula AS, Belisário CJ, Lorenzo MG, Bezerra CM, Harry M, et al. Influence of the palm tree species on the variability of Rhodnius nasutus Stål, 1859 (Hemiptera, Reduviidae, Triatominae). Infect Genet Evol. 2011; 11(5): 869877. doi:10.1016/j.meegid.2011.02.008.

21. Fé NF, Magalhães LK, Fé FA, Arakian SK, Monteiro WM, Barbosa MGV. Ocorrência de triatomíneos em ambientes silvestres e domiciliares do município 
de Manaus, Estado do Amazonas. Rev Soc Bras Med Trop. 2009 Dez; 42(6): 6426. doi: 10.1590/s0037-86822009000600006.

22. Almeida PS, Júnior WC, Obara MT, Santos HR, Barata JMS, Faccenda O. Levantamento da fauna de Triatominae (Hemiptera:Reduviidae) em ambiente domiciliar e infecção natural por Trypanosomatidae no Estado de Mato Grosso do Sul. Rev Soc Bras Med Trop. 2008 Jul-Ago; 41(4): 374-380. doi:10.1590/ S0037-86822008000400010.

23. Caranha L, Lorosa ES, Rocha DS, Jurberg J, Galvão C. Estudo das fontes alimentares de Panstrongylus lutzi (Neiva \& Pinto, 1923) (Hemiptera:Reduviidae:Triatominae) no Estado do Ceará. Rev Soc Bras Med Trop. 2006 Jul-Ago; 39(4): 347-351. doi:10.1590/S0037-86822006000400006.

24. Garcia MHHM, Souza L, Souza RCM, Paula AS, Borges EC, Barbosa SE, et al. Occurence and variability of Panstrongylus lutzi in the State do Ceará, Brazil. Rev Soc Bras Med Trop. 2005 Sep-Oct; 38(5): 410-5. doi:10.1590/S003786822005000500010 .

25. Villela MM, Rodrigues VLCC, Casanova C, Dias JCP. Análise da fonte alimentar de Panstrongylus megistus (Hemiptera, Reduviidae, Triatominae) e sua atual importância como vetor do Trypanosoma cruzi, no Estado de Minas Gerais. Rev Soc Bras Med Trop. 2010; 43(2): 125-8. doi:10.1590/S003786822010000200004 .

26. Oliveira J, Marcet PL, Takiya DM, Mendonça VJ, Belintani T, Bargues MD, et al. Combined phylogenetic and morphometric information to delimit and unify the Triatoma brasiliensis species complex and the Brasiliensis subcomplex. Acta Trop. 2017 Jun; 170: 140-8. doi:10.1016/j.actatropica.2017.02.020.

27. Lilioso M, Pires-Silva D, Fontes FHM, Oliveira J, Rosa JA, Vilela RV, et al. Triatoma petrochiae (Hemiptera, Reduviidae, Triatominae): A Chagas disease vectors of $T$. brasiliensis species complex associated with reptiles. Infect Genet Evol. 2020 Aug; 82: 104307. doi:10.1016/j.meegid.2020.104307.

28. Brasil RP, Silva AR. Triatomine vectors of Trypanosoma cruzi-like trypanosomes in urban areas of São Luiz, Maranhão, Brasil. Trans R Soc Trop Med Hyg. 1983; 77(4): 568. doi:10.1016/0035-9203(83)90145-1.

29. Deane MP. Ocorrência do Trypanosoma conorrhini em "barbeiros" e em rato na cidade de Belém, Pará, e seu cultivo em meio de NNN. Rev Serv Espec Saude Publica. 1947; 1:433-448.

How to cite this article/ Como citar este artigo :

Alencar MJ, Silva ABR, Bezerr CM, Alencar CH, Martins VEP. Surveillance of Chagas disease vectors in Ceará State, Northeastern Brazil. J Health Biol Sci. 2021; 9(1):1-7. 